\title{
Local Public Servants and Employees in the Republic of Croatia: Legal Position and Obligations
}

\author{
DUŠKO LOZINA \& MIRKO KLARIĆ
}

\begin{abstract}
The topic of this paper is an analysis of the legal position of local public servants and employees in the Republic of Croatia as well as of their rights and obligations in the light of the enactment of the Public Servants and Employees in local and regional self-government Act. In this sense, the concept and characteristics of the status of the administrative public servant from the aspect of administrative theory and practice are analysed, a short comparative overview of different official systems in Europe is given, and the position of local public servants and employees in Croatia in the light of positive legal regulations is analysed. In the conclusion, an assessment of the existing officials system which is related to local public servants and employees in Croatia is given in the context of the stated modern systems of public administration. Also assessed is whether the enacted legal regulations will have a positive effect on the implementation of personnel policy, greater motivation and the work of local public servants and employees thereby finally resulting in a better and more quality functioning of local self-government
\end{abstract}

Key words: - Republic of Croatia $\bullet$ public administration $\bullet$ local self-government $\bullet$ local public servants and employees

Correspondence AdDress: Dr. Duško Lozina, University of Split, Faculty of Law, Department of Administrative Science, Domovinskog rata 8, 21000 Split, Croatia, e-mail: ante.lozina@st.net.hr. Mirko Klarić, MSc., University of Split, Faculty of Law, Department of Administrative Science, Domovinskog rata 8, 21000 Split, Croatia, email:mirko@inet.hr. 


\section{Introduction}

John holds that local behaviour plays a crucial role in national patterns of behaviour in Western Europe. In this sense, institutional 'restrictiveness' occurs as a result of the adoption of the idea of 'new public management', and as a result of the movement towards a decentralisation of the power of mainstream government. This includes the process of privatisation and contracting out, creating microagencies and introducing new forms of budgets (John, 2004: 9). A new approach to the problem area of local self-government strengthens the significance of citizen participation and so called good governance principles. Throughout Europe today ' civil charters' or 'charters on the quality of the public sector' are being brought in. (Löoffer, E., 2002: 28 - 29).

The mutual influence of global and local Lone $(1966,47)$ describes in the following way: ' local situations transform becoming partly wider 'global ' arenas and processes, while 'global' dimensions gain significance in relation to specific 'local' circumstances and through agreements and strategies of 'local' factors. Therefore there is a situation of continual interaction between local and cultural elements and global, cultural influences wherein both participate in the local cultural creation of local meanings and cultural forms (Schuerkens, U., 2004: 529).

It is obvious that the question of the relation between global and local is ever more present. In this sense, in the literature on the subject the concept of glocalisation is mentioned as a coined concept of globalisation and localisation. This term signifies the mutual permeation of the global and the local, their interrelatedness and the influence of the processes of globalisation on the local society. ${ }^{1}$

In this context, one must observe the global tendencies also at the European level. In order for the institutional capacities of the local unit to strengthen, a necessary space for their autonomy is created so that their capacity for administering public business is strengthened. The promotion of the principles of subsidiarity and the tendency towards a greater functionality and financial decentralisation, places new challenges before units of local and regional self-government and demands their organisational adaptation to new social and political circumstances.

An important part of this adaptation is the establishment of a coherent public servant system for local public servants and employees which would allow the implementation of a quality personnel policy. This should ensure a personnel structure of public servants in local units which is capable of meeting the challenge of redefining the roles and meaning of local services in a modern society. The topic of this article is the analysis of the legal position of local public servants and employees in the Republic of Croatia in the light of the enactment of the Public Servants and Employees Act in local and regional self-government. 
In this sense the concept and the characteristics of the status of the administrative public servant from the aspect of administrative theory and practice will be analysed, and a brief comparative overview of different public servant systems in Europe and the position of the local public servants and employees in Croatia in the light of positive legal regulations will be given.

In the concluding part of the paper an assessment of the existing public servant system related to local public servants and will be given in the context of the stated analyses of administrative theory and practice on the concept, role and status of administrative public servants in modern systems of public administration. It will also assess how the enacted regulations will influence the implementation of personnel policy and the work of local public servants and employees as well as the whole functioning of the system of local and regional self-government.

\section{The concept of administrative public servant in general}

The position and role of the administrative public servant within the framework of the system of public administration has long been the subject of administrative theory and practice. Many theoreticians have dealt with this topic and have emphasized certain aspects which they have held as important for carrying out this job.

Pušić states the content features of the administrative official. He determines public servants as the persons in the administrative organisations who do the work, be it manual or intellectual, as their main profession. ${ }^{2}$

Pušić claims that several different understandings of the administrative office exist. In the first one, the administrative service equates with the carrying out of political powers, and the administrative public servant is deemed the personal bearer of the part of the government monopoly of physical coercion, that is in the later form, the bearer of the authorities which indirectly emerge from that monopoly. According to the second understanding the administrative service is a benefit, a privilege which offers its bearer gain and puts him/her in a more favourable position from the other members of the community. The final consequences of this attitude towards the administrative service are tenure or purchase of administrative services and their being awarded as a reward for political and other favours and so on. The third is an understanding of administrative services as a social function which is necessary for the carrying out of some socially needed and useful work. From this understanding of public services also emerges the criterion of capability as a key instrument for the assessment and division of public servants. ${ }^{3}$ 
Relying on Pušić's analysis of various understandings of the public service, Marčetič states that there is in the majority of modern administrative systems a new understanding of the administrative service as a social function which is useful and necessary to the social community. She holds that the accelerated industrialisation and urbanisation of the countries of Western Europe and North America, towards the end of the $19^{\text {th }}$ and in the first half of the $20^{\text {th }}$ century have contributed to such an understanding. ${ }^{4}$

To ensure a quality carrying out of the administrative service as social functions there is an attempt to ensure the most quality personnel for work within the framework of the system of public administration. ${ }^{5}$

Borković firstly takes as a starting point the normative determination of the concept of the administrative public servant In this sense the definitions which determine the concept of the administrative public servant starting from the organisational aspect are mainly concerned with the organisational form of the body in which the public servant carries out the duties s/he is appointed for. Thereby, the concept of public servant covers all persons who do the specified listed duties, and whose work is considered as being the duties of the very state. ${ }^{6}$

The definitions which begin from the functional aspect, determine the concept of the public servants according to the content of the duties s/he performs as well as towards the other people who emerge from the carrying out of official functions. ${ }^{7}$

In modern administrative systems, Weber's understanding of bureaucracy as an optimal method of administration in an industrialised urban society comes to the fore. In this sense, Weber states that a bureaucratic type of administration has the following characteristics:

- the work is divided into organisations, organisational units and jobs in the form of firm authority,

- organisation is structurally hierarchical as a ladder of subordinate and superior positions and organisational units, and are monocratic in the sense that the decisions are made within the framework of one job,

- the foundation for effectiveness are work documents which only public servants in administration are familiar with,

- public servants are educated as specialists for their own job,

- public servants in an organisation work full- time (Pušić, E., 2007: 2192209). 
As far as the personal position of officials in a bureaucratic type of administrative organisations is concerned, the following characteristics can be emphasized:

- work in an organisation is a profession, that is, work for which the public servant is prepared educationally and for which s/he is emotionally tied,

- work in an organisation is the subject of social respect,

- one is appointed for a position,

- work in an administrative organisation is principally lifelong,

- for work in an administrative organisation, the public servant receives a salary which is not always meant to be equivalent to the effect, rather it is determined regardless of effectiveness, and it is more ample, and is in accordance with the criterion of appropriateness to the social position (Pušić, E., 2007:220),

- the public servant throughout his/her work life span advances in the service according to afore set rules. (Pusić, E., 2007: 220). ${ }^{8}$

In France, for example, the status of the public servants is regulated according to the principle of durability which is twofold:

- duration of the job which means that the public servant must carry out the job which is durable and for which budgetary means are secured,

- duration of the position of the public servant which is the result of his/her appointment for a permanent job. ${ }^{9}$

The elements of durability, stability and security are crucial for determining the position of the appointed public servants. However, on the other hand, their position is regulated by laws and provisions which means that they do not have gained rights confirmed by law and that the employer (government) can at any moment change the law and in a different way regulate their rights and obligations. $^{10}$

In Italy, officials are divided into four types (carriere): directive personnel, conceptual personnel, executive personnel and auxiliary personnel. In the service, the candidate is employed on the basis of a public job advertisement and must also fulfil the related conditions. ${ }^{11}$ As far as their position is concerned, decree no. 29 in 1993 regulates an equalisation of the employment of administrative officials with the employment of all other employed persons and evaluation according to civil and labour laws. The exception to this are judges, the army, state police, diplomats, prefects in provinces, university professors and researchers and general managers. $^{12}$

The German system of recruitment of public servants presents a classic example of public service in continental Europe. Its values are a faithful application of the law, professionalism and non-bias. Its weaknesses are inadequate flexibility and effectiveness, an unfavourable system of choice, advancement and salaries for public servants. All attempts at reform which have been attempted since the 
Second World War up to the beginning of the nineties of the twentieth century have been unsuccessful. ${ }^{13}$ At the beginning of the nineties small changes were made but the existing traditional model has still been kept. ${ }^{14}$

Today in the European Union legal regulation exists which influences the organisation of state administration and the creation of European administrative space. ${ }^{15}$ In this sense the role of SIGMA (Support for Improvement in Governance and Management) is more important. This contributes to the development of common administrative standards. SIGMA interprets the European Union's demands in relation to transition countries and shapes administrative standards and assesses the administrative capacities of transition countries.

However, the recommendations of SIGMA for the public servant service are:

- clear delineation between political and public servant position in administration

- recruitment and advancement in the administrative service must be founded on capability and competence

- hierarchical division in administrative organisation with external control of legality

- quality regulation of the obligations and rights of public servants and especially political neutrality and the position system, jobs of duties and rights of officials and especially of political neutrality and the system of position, work and engagements not connected with the characteristics of public servants.

- effective regulation of the processing of public servants' complaints and protection of their public servant rights,

- fairly regulating the performance appraisal of public servants and with enough guarantees so that public servants are protected from unfair assessment from superiors

- the system of payment must be established by law with a low level of freedom for superiors in the determination of salaries of individual public servants,

- administrative mechanisms must ensure the application of single standards throughout the whole administration independent of whether some administrative body is expressed or particularly in authority (Koprić, I., 2006: 132). ${ }^{16}$ 


\section{The legal position of local public servants in Croatia}

In the Republic of Croatia, according to the principle of subsidiary, the system of local self-government is separate from the system of state administration. Croatia has ratified the European Charter on local self-government and has included the content of its provisions into its own legal system. ${ }^{17}$ Based on these provisions citizens are guaranteed the right to local self-government and the jobs of the local and regional domain are regulated by law given that during the determination of authority for their functioning the bodies that are closer to citizens have the advantage. Autonomy of local and regional units of self-government in the performing of jobs within their authority, and also autonomy in the management of their own funds is guaranteed. ${ }^{18}$

Due to this, the position of local public servants and employees is special in relation to the position of state public servants and employees. Even though the work local public servants and employees do really does resemble the work which state civil servants and employees perform, because of the particular legal position of local and regional units of self-government and their constitutional and legal autonomies, it is necessary to regulate the position of local public servants and employees with a special legal Act.

To date the legal position of local public servants and employees was regulated by the State Public Servants and Employees Act in 2001 and by the Employment Act as a general regulation. However the State Public Servants and Employees Act did not prove to be appropriate enough to regulate the legal position of local public servants and employees employed in government bodies. ${ }^{19}$

It is precisely because of this that the enactment of a special public servants law came into force which could regulate the position of local public servants and employees. ${ }^{20}$ The afore mentioned is supposed to reflect the existing system of local and regional self-government and the adjusted domain of work which local public servants and employees perform (further referred to as Act).

The Act was enacted in July 2008 with its full title being Public Servants and Employees in local and regional self-government Act. ${ }^{21}$

According to the legal provisions, public servants are people who in administrative bodies of local units as a regular profession perform the duties in the self-government domain of local units and duties of the state administration entrusted to those units in accordance with the Constitution and the law.

Public servants are also people who in the administrative bodies of local units carry out general, administrative, financial-planning, material-financial, accountancy, information technology and other specialist work. 
Employees are people who in administrative bodies of local units carry out auxiliary-technical and other work the performance of which is necessary in order that the performance of work in the self-government domain of administrative bodies of local units be legally valid and uninterrupted.

The collective agreement can regulate the material and other rights of public servants and employees in administrative bodies of local units. Collective agreements are formulated by authorised union representatives and the municipal head, mayor and county head.

The rule book on internal order is created especially for each administrative body or as common rule book for several administrative bodies. The rule book on internal order for the administrative municipal body is created by the municipal head. For the administrative body of the city it is the mayor and for the administrative county body it is the county head. The rule book was created at the suggestion of the head of administrative bodies.

The general conditions for acceptance into the service of local public servants and employees are:

- majority

- citizenship of the Republic of Croatia

- medical capacity for performing the duties of the position for which he person is employed.

Besides these conditions which are regulated by law, there is a provision for the introduction of additional conditions which must be fulfilled when being employed in the service (certain education and qualifications, passing the particular state examination, work experience in appropriate jobs, knowledge of a certain foreign language, particular knowledge and skills, particular medical capacity and so on).

An appropriate education and qualification are specified as particular conditions for entry into the service.

As obstacles to entry into the service criminal acts and other obstacles are specified.

Criminal acts which prevent entry into the local service are:

- against body and life,

- against the freedom and human and citizen rights,

- against the Republic of Croatia,

- against values protected by international law,

- against sexual freedom and sexual morality, 
- against marriage, family and youth,

- against property,

- against the security of payment transactions and doing business,

- against the judiciary,

- against the authenticity of documents,

- against public order,

- against official duties.

Other obstacles for entry into the service include that a person cannot be employed in the administrative body of a local unit if $\mathrm{s} / \mathrm{he}$ has committed a serious breach of official duty within a period of 4 years from cessation of service or a person whose service in an administrative body of a local unit has ceased because $\mathrm{s} / \mathrm{he}$ did not perform satisfactorily in the trial period over a period of four years since cessation of service.

People are employed in the service on the basis of public job advertisement unless otherwise specified by law. The job advertisement must be published in the official gazette of the Republic of Croatia 'Narodne novine' and can be published in the daily or weekly press.

The job vacancy is not advertised:

- when recruiting into the service on a temporary basis apart from the recruitment of trainees,

- when retaining in the service a trainee who has passed the specialist state examination,

- in recruitment into the service of person who, on the basis of a contract of award of a scholarship or schooling awarded on the condition of working for a certain time in the service in administrative body of a local unit,

- in the case of recruitment into service of a person employed in a government body, or corporation with public powers or administrative body of the same or other local unit.

- In the case of recruitment to service of a person employed in a government body, a corporation with public powers or administrative body of the same or other local unit, a written agreement between the head of the administrative body into which the person is recruited into service and the head of the administrative body. In other words, the head of the government body or authorised representative of the corporation where the person has worked to date together with his/her preceding consent if the law has no other regulation.

The public servant is responsible for a breach in official duties. Criminal liability does not exclude responsibility for a breach in official duty if the criminal act which is the subject of the criminal proceeding also represents a breach in official duty. Being released from criminal liability does not presume being released from 
the responsibility for a breach in official duty if the criminal act also represents a breach in official duty.

Breaches in official duties are divided into more and less serious. Serious breaches in official duty are regulated by law and less serious ones by the law and the rulebook on internal order.

More serious breaches in official duty are:

- non-performance, unconscientiousness, late or negligent performance of official duties,

- unlawful work or omissions to undertake measures or actions for which the official has the authority in order to prevent illegality,

- giving wrong information which influences a decision or the occurrence of negative consequences,

- abuse of position,

- exceeding powers of service,

- refusal to carry out task without a justifiable reason,

- unauthorised rendering of service using means intended for the performance of work,

- destruction, removal without authorisation, making available information related to the performance of service with a established level of confidentiality in accordance with a particular law,

- carrying out activities which are in contradiction to the duties of the work position or without former authorisation of the head of the administrative department, that is municipal head, mayor and county head,

- preventing citizens or corporations from exercising their legal rights to the submission of requests, appeals, complaints, petitions or from exercising other legal rights,

- inappropriate behaviour which damages the reputation of the service,

- unjustified absence from work from two to four days in a row,

- the use of unauthentic documents in order to gain rights related to the service,

- causing greater material damage in the service or related to the service intentionally or through gross carelessness,

- limiting or denying rights established by the Public Servants Act to a public servant who reports to authorised persons or bodies suspicions of corruption, or the harassment of that public servant,

- other serious official duties regulated by particular laws.

Minor breaches of official duty are:

- continual tardiness at work,

- leaving the work premises during work hours without the authorisation or justified reason, 
- carelessness in the keeping of documents, information or other confidential documentation,

- unjustified absence from work of one day,

- non-informing the authorised official about the inability to come to work within 24 hours without a justifiable excuse,

- other less serious breaches of official duties which are regulated by the rulebook on internal order.

The head of the administrative body or the person whom that head has authorised in writing decides on minor breaches of official duty at the first level. At the second level the authorised court decides. At the first level for minor breaches of duty by the head of the administrative body the municipal head, mayor or county executive decide.

The minor breaches in duties of the head of the administrative body is decided upon at the first level by the authorised official court and at the second level by the Higher officials court organised for government public servants.

The authorised public servant court decides about the more serious breaches in official duty at the first level and the High official court organised for public servants decides at the second level.

Official courts are organised in counties and the City of Zagreb. The president and members of the official court are appointed by the county councils, that is, the town council of the City of Zagreb.

Large towns that have a population of over 35,000 and town centres of counties can independently organise the official court authorised for the implementation of proceedings due to more serious breaches of official duty against public servants of administrative city bodies. In that case the president and members are appointed by the town council.

Official courts have a president and at least six members. The President and at least two other members are appointed who are qualified lawyers who have passed the bar examination. The public servants court decides in a council of three members who appoint the president of the official court for each individual case. The council is always presided over by a member who is a qualified lawyer who has passed the bar examination.

Punishments for minor breaches of official duty are a warring, fine of up to $10 \%$ of the public servant's salary paid in the month when the punishment is given. A public warning is placed on the notice board of the administrative body in which the official is employed. 
Punishments for major breaches of official duty are fines from one to six months, at a monthly amount of $20 \%$ of the total salary paid out in the month when the punishment is given, demotion to a lower job position within the same level of education, probationary punishment of cessation of service and cessation of service.

\section{Conclusion}

The topic of this paper was the analysis of the legal position of public servants and employees who work in units of local and regional self-government in the Republic of Croatia, in the context of a classical approach to public servant systems which dominates in continental European administrative theory and practice.

The analysis of the result of the enactment of the Public Servants and Employees Act in local and regional self-government was stated. This law for the first time in a systematic way legally regulated their position. This in turn opened the way for a single regulation of the position of local public servants and employees independent of which local unit they worked in.

However, when interpreting the Act's provisions, one gets the impression that it represents a compilation of various versions of the law by which the position of the government official is regulated and takes too little into account the specific work conditions and function of local units. In particular, this can be seen in the case of some concrete questions such as responsibility of local public servants and employees, their incentives and rewards and so on.

It seems that the problem of responsibility of local public servants and employees is not regulated enough in a quality way because solutions are copied which apply to government civil servants while local public servants are in a different position. The position mentioned here emerges from the different nature of administrative bodies of local units, where a direct relation between the head of local units and public servants who are directly subordinate to them exists. While in administrative bodies of mainstream government there exists a more complex hierarchical relation with a strongly expressed relation of impersonal superiority and subordination in local units where the interaction between the heads of bodies and officials who work in them more direct and the problems which arise in the life of the local society much more often demand faster and more concrete action of local units. It is due to this that the questions like responsibility of officials for work, the quality of their work and the general system of incentives and rewarding of public servants are somewhat different and perhaps somewhat greater freedom should be left to the heads of local unit so that over formalisation be avoided. 
However, independent of these quandaries, the enactment of the Officials and Employees Act who work in local and regional units of self-government represents a positive step in the development of the Croatian system of local and regional sell-government because for the first time systematically and substantially the legal position as well as the rights and duties of coal public servants and employees has been regulated by following some basic characteristics which are generally present in every service system.

Even given all the quandaries and possible weaknesses of the enacted Act, its enactment should be welcomed and its eventual weaknesses which are shown though its practical application in practise should be thoroughly analysed, and, through quality prepared applied legal amendments those weaknesses should be eradicated.

\section{Notes}

${ }^{1}$ Glocality mantains localness in a global context. The events which occur at a global level, mediated by the media influence the local surroundings, and those from the local culture which are by their own content interesting are in a media way globally compared (Milardović, A. Riggs, F. W. - Teune, H., 2002.: 120).

2 Pusić states that in administrative organizations two other categories of people are also employed: political functionaries and temporary associates. According to Pusić, political functionaries are people who are in a formally established way representatives of resolute political bodies, that is political members who are voters, but whose function in concrete administrative organization is not a profession. Temporary associates are actually people who in administrative organization work temporarily, either because they are necessary to the organization for the limited work they do, or because it is work they can only perform partly during work hours, or it is work the nature of which has no professional character (Pusić, E., 2003: 203). The same division is presented by Blažević, who points out also the existence of two different models of staffing in administration: spoils system and merit system (Blažević, R., 2004: 97 - 101).

3 Besides the criterion of capability, Pusić states that from the understanding of the administrative service as social functions, also emerge the criteria of legal connection and responsibility of officials towards citizens, as well as the specific etiquette of administrative service. Pusić states that the understandings of the public service as powers and as benefits so interrelated that it is difficult in all situations to establish which is historically older (Pusić, E., 2003: 210).

${ }^{4}$ Marčetić states how life in cities has brought many risks and instabilities, and has created new needs. As an answer to this the government has developed steps of regulatory intervention due to stabilization of agriculture and preventing economic crisis and has developed a range of government services. Such a situation has also radically changed the role of public officials in society. The constantly more numerous and complex jobs can no longer be performed by laypersons and government favorites but rather by paid professionals who are not primarily the bearers of powers and benefits but bearers of social or public functions (Marčetić, G., 2006: 111).

5 In this sense the question of motivation in work in administrative organizations arises. Šimonović states that the connection between the characteristic of employment and the 
motivation for employment is established via work values. He determines the work values which someone believes to be desirable and expects that they will appear in a certain profession. The level to which the characteristic of employment in administrative bodies stipulate the achievement of important work values, the indicator is the motivating activity on employment (Šimonović, I., 1984: 16 - 26).

${ }^{6}$ Borkovic states that the question of how widely the concept of officials in an organizational sense primarily depends on the form of the organization of public administration and within that organization about the organizational forms in which officials work (Borković, I., 1999: 36).

${ }^{7}$ Borković mentions how former theoretical viewpoints connected the functional concept of the public official for the working of the public service and this understanding is still present in legal theory today. In addition, he states the viewpoints of the French court practice in the approach to defining officials which also starts from the functional concept of the public official (Borković, I., 1999: 36 - 37).

8 The social consequence of the bureaucratic type of administration according to Weber, is risk ranking, which is expressed in he principle of the equality of citizens before the law. In the assessment of scale consequences of the bureaucratic type of administration Weber is seen as partially contradictory. Weber believes that expert bureaucracy in the end is superior over every inexpert politician. On the other hand, Weber points out the circumstances that bureaucracy is linked to power, that is works for every boss and that the necessity of it does not increase its power (Pusić, E., 2007: 220 - 221).

${ }_{9}$ The appointment of the public servant also gives an element of durability. It can stop with the performing of its functions only after procedures which ensure its special protection (Braibant, G., 2002: 277).

10 Therefore, government officials do not form contracts like workers in the private sector; The collective or individual contracts are not applied to them but the law. The expression „contractual politics“, which is often used and especially in paying officials, fundamentally has no basis. It assumes that the government holds negotiations with the unions but only the government can put the formulated agreement into written rules. (Braibant, G., 2002: 277 278).

11 The positive conditions are citizenship, state of health, formal education. Negative conditions are that the candidate has not his/her lost civil rights, that a security measure for forbidding the carrying out of public service has been imposed nor the police security measures imposed, and isn't bankrupt (Pusić, E., 1997: 267 - 268).

${ }^{12}$ Therefore public servants are in a contractual relation. Thereby the union gains an important role in the personnel system because on behalf of the officials a collective agreement is formed with the government as their employer and relationship with their legal public. Expert circles in Italy have quite critically assessed the stated reform. In this way objections are emphasized that it is a single experiment in democratic political systems, arising as a result of the influence of unions and overestimating the market, that certain administrative courts have developed successful practice related to disputes on the relation of officials which regular courts won't achieve, that the intentions of the decree to increased the effectiveness of the Italian administration will be difficult to achieve considering the tradition of irresponsibility, negligible effort. Patrimonial understanding of the service and extreme egalitarianism (Pusić, E., 1997: 272).

13 As reasons, disagreeing with the well placed interested sides nd especially the persons who have defended the traditional model of the public service (Bereufsbeamtemtum) (Wollman, H., 2003: 26).

${ }^{14}$ In this way the system of advancement is kept which traditionally differentiates „higher services“ (höherer Dienst), „middle-to-high services“ (gehoberen Dienst), „middle services“ 
(mittlerer Dienst) and „lower services“ (einfacher Dienst), „state officials“ (Beamten) from employees (Angestellte)) (Wollman, H., 2003: 30 - 31).

15 In forming the European administrative space the European Court of Justice has an important role. Its decisions have a strong effect on the development of the legal practice in the area of the European Union. For example according to the decision in case 149/1979 EC vs. Belgium every member state is obliged to ensure equal opportunity for employment of citizens of other member state countries in its own country in the whole public administration. It can only keep its own citizens in those jobs in administration which contain the execution of public-legal powers and protection of the general interest of the state. More on this topic in (Koprić, I., 2006: 131).

16 Koprić states how SIGMA in its documents established a list of questions which must be regulated by the law on public officials and sub-acts. In this way the following aims of the regulation of the position of administrative officials are emphasized: a) improvement of the professional level of officials so that the quality job performance is improved, b) giving certain measures of independence to officials who execute public powers, so that political abuse and poor administration be prevented., c) establishing appropriate ethical criteria in public administration , d) enabling the government to adjust administration to its changing needs, e) ensuring a social legitimacy of public administration in the sense that citizens and public officials accept the standards of professionalism in administration, f) make a career in administration attractive and retain the quality officials in administration (Koprić, I. 2006: 132 $-133)$.

17 Talking about the principle of subsidiarity and its influence on the organization of local and regional self-government, Bakota holds that the European Charter on local self-government and the draft of the European Charter on regional self-government create starting points for the establishment of a common European institutional model of local and regional selfgovernment. Therein is the basic question which appears at the establishment of that institutional model - the question of authority of where should local units have the advantage over mainstream government, and the question of fiscal capacity and in general financial autonomy and independence of units of local and regional self-government in relation to mainstream government (Bakota, B., 2007: 117 - 118).

18 This guarantee represents a constitutional category and they are stated in art 132. -137 . The Constitution of the Republic of Croatia. More details are those guarantees formulated by law of which the most important one is the Local and Regional Self-government Act.

${ }_{19}$ In the literature it is generally stated that great problems exist given the expertise and education of the administrative staff in the state administration bodies as well as in the bodies of local and regional self-government. Marčetić states the fact in half of all positions officials are working who have only finished high school, $15 \%$ has a practical tertiary education and the rest are university educated officials. Amongst them is a big number of those who have a practical education while there are too little university educated experts in social areas. Marčetić in this sense proposes some basic suggestions for the improvement of the Croatian officials system where firstly he states the problem of the lack of officials law for local and regional officials and the need and the need for its swift enactment. (Marčetić, G., 2005: 316 - 323).

${ }^{20}$ It must be mentioned that it was precisely the Town Associations that were strong supporters of the enactment of a law which would in a holistic and thorough way regulate the status of officials and employees. In this sense they formulated their own bill on local public servants and employees.. (Kopajtich - Škrlec, N., 2007).

21 The Act came into force on 31. 07. 2008. Based on the provisions of that Act several legal regulations will be enacted: the provision of the classification of work position (brought in by the government of the Republic of Croatia), a special law by which the salaries of public servants and employees will be regulated according to provision art. 80 of the act, a rulebook 
on the content and means of personal inquest registers (brought in by the state secretary of the central state office for administration) (Kasabašić, Š.: 2008).

\section{References}

Bakota, B. (2007) Problem primjene načela supsidijarnosti (Osijek: Pravni fakultet Osijek).

Blažević, R. (2004) Upravna znanost: kompendij (Rijeka: Pravni fakultet u Rijeci).

Borković, I. (1999) Slǔ̌beničko pravo (Zagreb: Informator).

Braibant, G. (2002) Administrativno pravo Francuske (Beograd: CID \& Službeni list SRJ).

John, P. (2004) Local Governance in Western Europe (London - New Delhi: SAGE Publications).

Kasabašić, Š. (2008): Status lokalnih službenika i nmještenika. Primjena zakona o službenicima i namještenicima u lokalnoj i područnoj (regionalnoj) samoupravi, Informator, 5684-5685.

Kopajtich-Škrlec, N. (2007) Prijedlog zakona o službenicima i namještenicima u lokalnoj i područnoj (regionalnoj) samoupravi, Informator, 5544.

Koprić, I. (2006) Prilagodba hrvatskog službeničkog sustava Europskim standardima, u Koprić, I. (ur.): Javna uprava: nastavni materijali (Zagreb: Društveno veleučilište u Zagrebu \& Pravni fakultet u Zagrebu).

Löoffer, E. (2002) Defining and Measuring Quality in Public Administration in Building Better Quality Administration for the Public: Case studies from Central and Eastern Europe, in Caddy, J. \& Vintar, M., (Bratislava: NISPA).

Marčetić, G. (2005) Javni slǔ̌benici i tranæicija (Zagreb: Društveno veleučilište u Zagrebu \& Konrad Adenauer Stiftung).

Marčetić, G. (2006) Službenici u suvremeno doba, in Koprić, I. (ed.): Javna uprava: nastavni materijali, Zagreb: Društevno veleučilište u Zagrebu i Pravni fakultet u Zagrebu).

Milardović, A., Riggs, F. W. \& Teune, H. (2002) Mali leksikon globalizacije (Zagreb: Centar za politološka istraživanja).

Pusić, E. (2007) Dř̌ava i dř̌auna uprava (Zagreb: Društveno veleučilište u Zagrebu \& Pravni fakultet u Zagrebu).

Pusić, E. et al (1997) Hrvatska središnja dř̌anna uprava i usporedni upravni sustavi (Zagreb: Školska knjiga).

Pusić, E. (2003) Nauka o upravi (Zagreb: Školska knjiga).

Schuerkens, U. (2004) Sociološko i antropološko istraživanje globalizacije i lokalizacije, Europski glasnik, 9(2004).

Šimonović, I. (1984) Utjecaj karakteristika zaposlenja na motiviranost za zapošljavanje u organima dræ̌avne uprave (Zagreb: IDIS).

Wollman, H. (2003) Suvremene upravne reforme u Njemačkoj, in Koprić, I. (ed.): Modernizacija hrvatske uprave (Zagreb: Društveno veleučilište u Zagrebu).

\section{Regulations}

Ustav Republike Hrvatske (pročišćeni tekst), Narodne novine No. 41/2001.

Zakon o radu (pročišćeni tekst), Narodne novine No. 137/2004.

Zakon o državnim službenicima i namještenicima, Narodne novine No. 27/2001.

Zakon o službenicima i namještenicima u lokalnoj i područnoj (regionalnoj) samoupravi, Narodne novine No. 86/2008.

Zakon o lokalnoj i područnoj (regionalnoj) samoupravi, Narodne novine . 33/2001, 60/2001, 129/2005, 109/2007. 